\title{
ZAKAT PROFESI (ZAKAT PENGHASILAN) \\ MENURUT HUKUM ISLAM
}

\author{
Tira Nur Fitria \\ STIE AAS Surakarta
}

Email: tiranurfitria@gmail.com

\begin{abstract}
This study aims to find out about the zakat profession (tithe income) in Islamic view (Islamic law). This research is qualitative descriptive. This study included literature to examine the written sources such as scientific journals, books referesni, literature, encyclopedias, scientific articles, scientific papers and other sources that are relevant and related to the object being studied. As for the object of study of this research is in the form of texts or writings that describe and explain about the profession zakat (tithe income). Results from this study is obligatory of Zakat profession together with the charity business and other income such as agriculture, livestock and trade. Limit nisab wealth derived from the business professions can be equated with charity nisab plant yield is 5 wasaq (about $750 \mathrm{~kg}$ of rice), with the obligation of zakat 5\% or 10\%, and is payable when earning achievements, rewards or wages of the profession. For kind of professions such as doctors in hospitals, teachers or lecturers who only received a fixed salary of the workings of government agencies, likened nisab nisabnya with gold and silver, which is 93.6 grams, with the obligation of zakat 2.5 percent, which is issued every one years, and having expended costs of basic necessities.
\end{abstract}

Keywords: zakat profession / income zakat, Islamic law

\section{PENDAHULUAN}

Zakat profesi merupakan salah satu kasus baru dalam fiqh (hukum Islam). Al-Quran dan al-Sunnah, tidak memuat aturan hukum yang tegas mengenai zakat profesi ini. Begitu juga ulama mujtahid seperti Abu Hanifah, Malik, Syafi $\wedge^{i}$, dan Ahmad ibn Hanbal tidak pula memuat dalam kitab-kitab mereka mengenai zakat profesi ini. Hal ini disebabkan oleh terbatasnya jenis-jenis usaha atau pekerjaan masyarakat pada masa Nabi dan imam mujtahid.

Jurnal Ilmiah Ekonomi Islam- Vol. 01, No. 01, Maret 2015
Sedangkan hukum Islam itu sendiri adalah refleksi dari peristiwa-peristiwa hukum yang terjadi ketika hukum itu ditetapkan.

Tidak munculnya berbagai jenis pekerjaan dan jasa atau yang disebut dengan profesi ini pada masa Nabi dan imam-imam mujtahid masa lalu, menjadikan zakat profesi tidak begitu dikenal (tidak familiar) dalam Sunnah dan kitab-kitab fiqh klasik. Dan adalah wajar apabila sekarang terjadi kontroversi dan perbedaan pendapat ulama di sekitar zakat profesi ini. Ada ulama yang mewajibkannya dan ada pula ulama yang secara apriori tidak mewajibkannya. 
Namun demikian, sekalipun hukum mengenai zakat profesi ini masih menjadi kontroversi dan belum begitu diketahui oleh masyarakat muslim pada umumnya dan kalangan profesional muslim di tanah air pada khususnya, kesadaran dan semangat untuk menyisihkan sebagian penghasilan sebagai zakat yang diyakininya sebagai kewajiban agama yang harus dikeluarkannya cukup tinggi. Artikel ini barangkali bisa kita jadikan semacam indikasi bagaimana kalangan profesional peduli terhadap masalah zakat profesi ini. Oleh karena itu, penelitian ini mencoba mengemukakan beberapa pokok pikiran berkenaan dengan hukum zakat profesi dengan judul zakat profesi dalam perspektif hukum islam (fiqh).

\section{PEMBAHASAN}

\section{Pengertian Profesi dan Zakat Profesi}

Zakat profesi terdiri dari dua kata yaitu zakat dan profesi. Dalam literatur fiqh klasik pengertian zakat adalah hak yang dikeluarkan dari harta atau badan. Sehubungan dengan hal ini, Wahbah al-Zuhayly mengemukakan bahwa zakat adalah penuanaian hak yang wajib yang terdapat dalam harta. Dalam kamus Bahasa Indonesia, profesi adalah bidang pekerjaan yang dilandasi pendidikan keahlian (keterampilan, kejujuran, dan sebagainya) tertentu (Kamus Bahasa Indonesia dalam Muhammad 2002: 58).

Zakat profesi adalah zakat yang di keluarkan dari hasil apa yang di peroleh dari pekerjaan dan profesinya. Misalnya pekerjaan yang menghasilkan uang baik itu pekerjaan yang dikerjakan sendiri tampa tergantung dengan orang lain, berkat kecekatan tangan ataupun otak (professional). Maupun pekerjaan yang dikerjakan seseorang buat pihak lain baik pemerintah, perusahaan, maupun perorangan dengan memperoleh upah yang diberikan, dengan tangan, otak, ataupun keduanya. Penghasilan dari pekerjaan seperti itu berupa gaji, upah, ataupun honorarium. Yang demikian itu apabila sudah mencapai nisabnya dan haulnya pendapatan yang ia hasilkan harus di keluarkan zakatnya. (Qardawi, 2007: 459).

Menurut Wikipedia, zakat profesi adalah zakat yang dikeluarkan dari penghasilan profesi ( guru, dokter, aparat, dan lain-lain ) atau hasil profesi bila telah sampai pada nisabnya. Berbeda dengan sumber pendapatan dari pertanian, peternakan dan perdagangan, sumber pendapatan dari profesi tidak banyak dikenal di masa generasi terdahulu.

Dalam pandangan al-Ghazali zakat merupakan jenis ibadah yang berbentuk ritual sekaligus material tidak seperti ibadah syahadat, shalat atau puasa (Al-Ghazali dalam Muhammad Hadi 2010: 68). Untuk bisa sampai ke arah sana diperlukan pemahaman yang memadai untuk menyadarkan bahwa kewajiban zakat bukanlah sekedar amaliah ritual mahdhah saja, tetapi juga memiliki makna kewajiban sosial. Zakat adalah kesalehan diri melalui ikhtiar sosial. Agar sampai kepada kesadaran seperti itu diperlukan penyadaran yang dibarengi dengan tindakan amal-amal sosial, termasuk mengeluarkan zakat, infak dan shadaqah. Karena dalam ajaran zakat ini pandangan dan komitmen sosialnya begitu jelas, bahkan dari titik kepentingan yang paling menyentuh hajat orang banyak, yaitu pemenuhan kebutuhan ekonomi.

Secara umum zakat profesi menurut putusan Tarjih Muhammadiyah adalah zakat yang dikeluarkan dari hasil usaha yang halal 
yang dapat mendatangkan hasil atau uang, relatif banyak dengan cara yang halal dan mudah, baik melalui keahlian tertentu maupun tidak. Sedangkan dalam pemahaman Zamzami Ahmad, zakat profesi adalah zakat penghasilan yang didapat dan diterima dengan jalan yang halal dalam bentuk upah, honor ataupun gaji. (Inoed,, $2005: 50$ )

\section{Sejarah Zakat Profesi}

Zakat profesi merupakan salah satu kasus baru dalam fiqh (hukum Islam). Al-Quran dan al-Sunnah, tidak memuat aturan hukum yang tegas mengenai zakat profesi ini. Begitu juga ulama mujtahid seperti Abu Hanifah, Malik, Syafi^i, dan Ahmad ibn Hanbal tidak pula memuat dalam kitab-kitab mereka mengenai zakat profesi ini. Hal ini disebabkan oleh terbatasnya jenis-jenis usaha atau pekerjaan masyarakat pada masa Nabi dan imam mujtahid. Sedangkan hukum Islam itu sendiri adalah refleksi dari peristiwa-peristiwa hukum yang terjadi ketika hukum itu ditetapkan. Tidak munculnya berbagai jenis pekerjaan dan jasa atau yang disebut dengan profesi ini pada masa Nabi dan imam-imam mujtahid masa lalu, menjadikan zakat profesi tidak begitu dikenal (tidak familiar) dalam Sunnah dan kitab-kitab fiqh klasik. Dan adalah wajar apabila sekarang terjadi kontroversi dan perbedaan pendapat ulama di sekitar zakat profesi ini. Ada ulama yang mewajibkannya dan ada pula ulama yang secara apriori tidak mewajibkannya. Namun demikian, sekalipun hukum mengenai zakat profesi ini masih menjadi kontroversi dan belum begitu diketahui oleh masyarakat muslim pada umumnya dan kalangan profesional muslim di tanah air pada khususnya, kesadaran dan semangat untuk menyisihkan sebagian penghasilan sebagai zakat yang diyakininya sebagai kewajiban agama yang harus dikeluarkannya cukup tinggi. Forum diskusi ini barangkali bisa kita jadikan semacam indikasi bagaimana kalangan profesional kita sangat respek terhadap masalah zakat profesi ini.

Zakat profesi adalah masalah baru, tidak pernah ada dalam sepanjang sejarah Islam sejak masa Rasulullah SAW hingga tahun 60an akhir pada abad ke-20 yang lalu, ketika mulai muncul gagasan zakat profesi ini. Penggagas zakat profesi adalah Syeikh Yusuf Qaradhawi dalam kitabnya Fiqh Az Zakah, yang cetakan pertamanya terbit tahun 1969. Namun nampaknya Yusuf Qaradhawi dalam hal ini mendapat pengaruh dari dua ulama lainnya, yaitu Syeikh Abdul Wahhab Khallaf dan Syeikh Abu Zahrah.

Kajian dan praktik zakat profesi mulai marak di Indonesia kira-kira sejak tahun 90-an akhir dan awal tahun 2000-an. Khususnya setelah kitab Yusuf Qaradhawi tersebut diterjemahkan ke dalam bahasa Indonesia oleh Didin Hafidhuddin dengan judul Fikih Zakat yang terbit tahun 1999. Sejak saat itu zakat profesi mulai banyak diterapkan oleh lembaga pengelola zakat di Indonesia, baik BAZ (badan amil zakat) milik pemerintah, baik BASDA atau BASNAZ, maupun LAZ (lembaga amil zakat) milik swasta, seperti PKPU, Dompet Dhuafa, dan sebagainya.

\section{Profesi yang di Zakati}

Barangkali bentuk penghasilan yang paling menyolok pada zaman sekarang ini adalah apa yang diperoleh dari pekerjaan dan profesinya. Pekerjaan yang menghasilkan uang ada dua macam. Yang pertama adalah pekerjaan yang dikerjakan sendiri tanpa 
tergantung kepada orang lain, berkat kecekatan tangan ataupun otak. Penghasilan yang diperoleh dengan cara ini merupakan penghasilan profesional, seperti penghasilan seorang doktor, insinyur, advokat seniman, penjahit, tukang kayu dan lain-lainnya. (Daradjat, 1996 : 56)

Yang kedua, adalah pekerjaan yang dikerjakan seseorang buat pihak lain-baik pemerintah, perusahaan, maupun perorangan dengan memperoleh upah, yang diberikan, dengan tangan, otak, ataupun kedua-duanya. Penghasilan dari pekerjaan yang dikerjakan untuk orang atau pihak lain dengan imbalan mendapat upah atau honorarium seperti pegawai negeri atau swasta. (Hasan, 2001 : 204)

Penghasilan dan profesi dapat diambil zakatnya bila sudah setahun dan cukup senisab. Jika kita berpegang kepada pendapat Abu Hanifah, Abu Yusuf, dan Muhammad bahwa nisab tidak perlu harus tercapai sepanjang tahun, tapi cukup tercapai penuh antara dua ujung tahun tanpa kurang di tengahtengah kita dapat menyimpulkan bahwa dengan penafsiran tersebut memungkinkan untuk mewajibkan zakat atas hasil penghasilan setiap tahun, karena hasil itu jarang terhenti sepanjang tahun bahkan kebanyakan mencapai kedua sisi ujung tahun tersebut. Berdasar hal itu, kita dapat menetapkan hasil penghasilan sebagai sumber zakat, karena terdapatnya illat (penyebab), yang menurut ulama-ulama fikih sah, dan nisab, yang merupakan landasan wajib zakat.

Dikarenakan Islam mempunyai ukuran bagi seseorang - untuk bisa dianggap kaya yaitu 12 Junaih emas menurut ukuran Junaih Mesir lama maka ukuran itu harus terpenuhi pula buat seseorang untuk terkena kewajiban zakat, sehingga jelas perbedaan antara orang kaya yang wajib zakat dan orang miskin penerima zakat.

Dalam hal ini, mazhab Hanafi lebih jelas, yaitu bahwa jumlah senisab itu cukup terdapat pada awal dan akhir tahun saja tanpa harus terdapat di pertengahan tahun. Ketentuan itu harus diperhatikan dalam mewajibkan zakat atas hasil penghasilan dan profesi ini, supaya dapat jelas siapa yang tergolong kaya dan siapa yang tergolong miskin, seorang pekerja profesi jarang tidak memenuhi ketentuan tersebut. (Juhairi, 1995 : 45)

Mengenai besar zakat, Penghasilan dan profesi dalam fikih masalah khusus mengenai penyewaan. Seseorang yang menyewakan rumahnya dan mendapatkan uang sewaan yang cukup nisab, bahwa orang tersebut wajib mengeluarkan zakatnya ketika menerimanya tanpa persyaratan setahun. Hal itu pada hakikatnya menyerupai mata penghasilan, dan wajib dikeluarkan zakatnya bila sudah mencapai satu nisab.

Hal itu sesuai dengan apa yang telah kita tegaskan lebih dahulu, bahwa jarang seseorang pekerja yang penghasilannya tidak mencapai nisab seperti yang telah kita tetapkan, meskipun tidak cukup di pertengahan tahun tetapi cukup pada akhir tahun. Ia wajib mengeluarkan zakat sesuai dengan nisab yang telah berumur setahun.

Akibat dari tafsiran itu, kecuali yang menentang, adalah bahwa zakat wajib dipungut dari gaji atau semacamnya sebulan dari dua belas bulan. Karena ketentuan wajib zakat adalah cukup nisab penuh pada awal tahun atau akhir tahun.

Pendapat guru-guru besar tentang hasil penghasilan dan profesi dan pendapatan dari gaji atau lain-lainnya yaitu kekayaan yang 
diperoleh seseorang Muslim melalui bentuk usaha baru yang sesuai dengan syariat agama. Jadi pandangan fikih tentang bentuk penghasilan itu adalah, bahwa ia adalah "harta penghasilan." Sekelompok sahabat berpendapat bahwa kewajiban zakat kekayaan tersebut langsung, tanpa menunggu batas waktu setahun.

Yang diperlukan zaman sekarang ini adalah menemukan hukum pasti "harta penghasilan" itu, oleh karena terdapat hal-hal penting yang perlu diperhatikan, yaitu bahwa hasil penghasilan, profesi, dan kekayaan nondagang dapat digolongkan kepada "harta penghasilan" tersebut. Bila kekayaan dari satu kekayaan, yang sudah dikeluarkan zakatnya, yang di dalamnya terdapat "harta penghasilan" itu, mengalami perkembangan, misalnya laba perdagangan dan produksi binatang ternak maka perhitungan tahunnya disamakan dengan perhitungan tahun induknya. Hal itu karena hubungan keuntungan dengan induknya itu sangat erat.

Berdasarkan hal itu, bila seseorang sudah memiliki satu nisab binatang ternak atau harta perdagangan, maka dasar dan labanya bersama-sama dikeluarkan zakatnya pada akhir tahun. Ini jelas. Berbeda dengan hal itu, "harta penghasilan" dalam bentuk uang dari kekayaan wajib zakat yang belum cukup masanya setahun, misalnya seseorang yang menjual hasil tanamannya yang sudah dikeluarkan zakatnya $1 / 10$ atau $1 / 20$, begitu juga seseorang menjual produksi ternak yang sudah dikeluarkan zakatnya, maka uang yang didapat dari harga barang tersebut tidak dikeluarkan zakatnya waktu itu juga. Hal itu untuk menghindari adanya zakat ganda, yang dalam perpajakan dinamakan "Tumpang Tindih Pajak."
Yang jelas pendapat tersebut diatas adalah pendapat ulama- ulama fikih meskipun yang terkenal banyak di kalangan para ulama fikih itu adalah bahwa masa setahun merupakan syarat mutlak setiap harta benda wajib zakat, harta benda perolehan maupun bukan. Hal itu berdasarkan hadis-hadis mengenai ketentuan masa setahun tersebut dan penilaian bahwa hadis-hadis tersebut berlaku bagi semua kekayaan termasuk harta hasil usaha.

\section{Hukum Zakat Profesi}

Profesi merupakan bentuk usaha-usaha yang relatif baru yang tidak dikenal pada masa pensyariatan dan penetapan hukum Islam. Karena itu, sangat wajar bila kita tidak menjumpai ketentuan hukumnya secara jelas (tersurat) baik dalam al-Quran maupun dalam al-Sunnah.

Menurut ilmu ushul fiqh (metodologi hukum Islam), untuk menyelesaikan kasuskasus yang tidak diatur oleh nash (al-Quran dan al-Sunnah) secara jelas ini, dapat diselesaikan dengan jalan mengembalikan persoalan tersebut kepada al-Quran dan sunnah itu sendiri. Pengembalian kepada dua sumber hukum itu dapat dilakukan dengan dua cara, yakni dengan perluasan makna lafaz dan dengan jalan qias (analogi).

Kewajiban berzakat ini berdasarkan keumuman kandungan makna Al-Qur'an surah at-Taubah:103 dan surah al-Baqoroh: 267. Disamping itu juga berdasarkan pada tujuan disyariatkannya zakat, seperti untuk membersihkan dan mengembangkan harta serta menolong para mustahik. Zakat profesi juga mencerminkan rasa keadilan yang merupakan ciri utama ajaran Islam, yaitu 
kewajiban zakat pada semua penghasilan dan pendapatan.

Adanya perintah zakat adalah untuk menciptakan rasa sosial dan keadilan. Jika petani yang menggarap sawah atau ladang dituntut untuk menegluarkan zakat setiap kali panen bila mencapai nasab, sementara mereka yang bergelut di sektor usaha dan profesi berpenghasilan lebih besar yang lebih mudah tidak di tuntut untuk berzakat.

Alasan diwajibkannya zakat profesi (zakat penghasilan) dapat di tafsirkan dari ayat QS. Al-Baqarah 267 sebagai berikut:

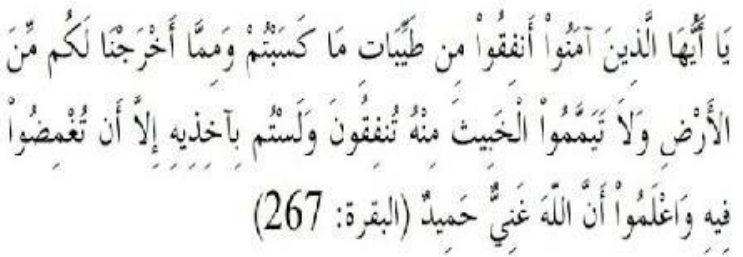

"Hai orang-orang yang beriman, nafkahkanlah (di jalan Allah) sebagian dari hasil usahamu yang baik-baik dan sebagian dari apa yang kami keluarkan dari bumi untuk kamu. dan janganlah kamu memilih yang buruk-buruk lalu kamu menafkahkan daripadanya, padahal kamu sendiri tidak mau mengambilnya melainkan dengan memincingkan mata terhadapnya. dan Ketahuilah, bahwa Allah Maha Kaya lagi Maha Terpuji.

\section{Penjelasan ayat QS. Al-Baqarah 267 adalah:}

Kata "ما" adalah termasuk kata yang mengandung pengertian yang umum, yang artinya apa saja, sebagian dari hasil (apa saja) yang kamu usahakan yang baik-baik. Maka jelaslah, bahwa semua macam penghasilan (gaji, honorarium, dll) terkena wajib zakat berdasarkan ketentuan QS. Al -Baqarah : 267 tersebut yang mengandung pengertian yang umum, asal penghasilan tersebut telah melebihi kebutuhan pokok hidupnya dan keluarganya (sandang, pangan, papan, beserta alat-alat rumah tangga, alat-alat kerja atau usaha, kendaraan, dan lain-lain yang tidak bisa diabaikan), bebas dari beban hutang, telah genap setahun kepemilikannya dan telah mencapai nishab.

Sayyid Quthb dalam tafsirnya Fi Zhilalil Qur'an, menafsirkan surat al-Baqarah :267, bahwa nash tersebut mencakup seluruh hasil usaha manusia yang baik dan halal dan mencakup pula seluruh yang dikeluarkan Allah SWT dari dalam dan atas bumi, baik yang terdapat di zaman Rasulullah SAW., maupun di zaman sesudahnya.

Sedangkan menurut Syarifuddin (1987) menjelaskan bahwa penggunaan kata "Maa" dalam ayat tersebut di atas adalah mencakup segala apa-apa yang diperoleh melalui hasil usaha atau jasa, dan juga apa-apa yang dikeluarkan atau diusahakan dari bumi. Dengan argumentasi bahwa kekuatan lafadz umum terhadap semua satuan pengertian yang tercakup di dalamnya secara pasti, sebagaimana penunjukkan lafadz khusus terhadap arti yang terkandung di dalamnya. Penggunaan lafadz umum untuk semua satuan pengertian ini berlaku sampai ada dalil lain yang membatasinya. Hamid (2005) juga mengatakan bahwa kata dalam ayat tersebut memberikan legitimasi terhadap semua jenis usaha dan profesi yang dimiliki yang kesemuanya mendatangkan penghasilan yang cukup banyak, seperti pengacara, dokter ahli, jasa perhotelan, jasa penginapan, dan sebagainya. 
Kemudian dalam Surat at-Taubah :103 juga dinyatakan:

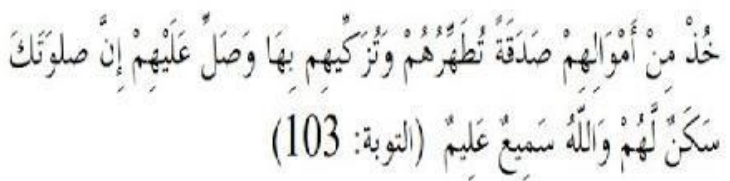

Artinya : "Ambillah sedekah (zakat) dari sebagian harta mereka, dengan sedekah itu kamu membersihkan dan mensucikan mereka, dan mendo'alah untuk mereka. Sesungguhnya do'a kamu itu (menjadi) ketentraman jiwa bagi mereka. Dan Allah Maha Mendengar lagi Maha Mengetahui." (at-Taubah : 103)

\section{Penjelasan ayat QS. At-Taubah: 103 sebagai berikut:}

Makna terminologi generik ayat tersebut menunjuk pada harta kekayaan, tidak menunjuk dari mana harta itu diperoleh (usaha) yang bernilai ekonomi, dan karena spektrumnya lebih bersifat umum, maka di dalamnya termasuk jasa/gaji yang secara rasional adalah bagian dari harta kekayaan, sehingga wajib dikeluarkan zakatnya.Selanjutnya dengan dasar as-Sunnah untuk mengukuhkan kewajiban zakat profesi, berdasarkan pada keumuman makna hadits. Yang antara lain hadits yang diriwayatkan oleh al-Bukhari sebagai berikut:

"Setiap orang muslim wajib bersedekah, Mereka bertanya: "Wahai Nabi Allah, bagaimana yang tidak berpunya?, Nabi menjawab:" Bekerjalah untuk mendapat sesuatu untuk dirinya, lalu bersedekah". Mereka bertanya kembali: "Kalau tidak mempunyai pekerjaan?, Nabi menjawab: "Kerjakan kebaikan dan tinggalkan keburukan, hal itu merupakan sedekah." (H.R Bukhari)

Yusuf Qardlawi menafsirkan keumuman dari makna hadits tersebut di atas bahwa zakat wajib atas penghasilan sesuai dengan tuntunan Islam yang menanamkan nilai-nilai kebaikan, kemauan, berkorban, belas kasihan, dan suka memberi dalam jiwa seorang muslim. Untuk itu Nabi mewajibkan pada setiap muslim mengorbankan sebagian harta penghasilannya atau apa saja yang bisa ia korbankan.

Adapun dalam hal qiyas, wajibnya zakat profesi diqiyaskan pada tindakan khalifah Mu'awiyah yang mengenakan zakat atas pemberian menurut ukuran yang berlaku dalam negara Islam, karena beliau adalah khalifah dan penguasa umat Islam. Dan perbuatan khalifah Umar Ibnu Abdul Aziz yang memungut zakat pemberian (u'tiyat) dan hadiah. Juga memungut zakat dari para pegawainya setelah menerima gaji, serta menarik zakat dari orang yang menerima barang sitaan (mazalim) setelah dikembalikan kepadanya.

Menurut para Imam Madzhab terjadi perbedaan pendapat. Menurut Imam Syafi'i, zakat penghasilan tidak wajib zakat meskipun ia memiliki harta sejenis yang sudah cukup nishab. Tetapi ia mengecualikan anak-anak binatang piaraan, di mana anak-anak binatang itu tidak dikeluarkan zakatnya bersamaan dengan zakat induknya yang sudah mencapai nishab.

Dan bila belum mencapai nishab, maka tidak wajib zakatnya. Dalam kitabnya alUmm, Imam Syafi'i mengatakan apabila seseorang menyewakan rumahnya kepada orang lain dengan harga 100 dinar selama 4 tahun dengan syarat pembayarannya sampai 
batas waktu tertentu, maka apabila ia telah mencapai satu tahun, ia harus mengeluarkan zakatnya untuk 25 dinar pada satu tahun pertama dan membayar zakat untuk 50 dinar pada tahun kedua, dengan memperhitungkan uang 25 dinar yang telah dikeluarkan zakatnya pada tahun pertama dan seterusnya, sampai ia mengeluarkan zakatnya dari 100 dinar dengan memperhitungkan zakat yang telah dikeluarkan, baik sedikit atau banyak.

Menurut Imam Malik, harta penghasilan tidak dikeluarkan zakatnya kecuali sampai penuh waktu setahun. Baik harta tersebut sejenis dengan harta yang ia miliki atau tidak, kecuali jenis binatang piaraan. Karena orang yang memperoleh penghasilan berupa binatang piaraan yang sejenis dan sudah mencapai nishab, maka ia harus mengeluarkan zakat dan keseluruhan binatang itu apabila sudah genap satu tahun. Dan apabila kurang dari satu nishab, maka tidak wajib zakat.

Dalam suatu kasus tentang seseorang yang memiliki 5 dinar hasil dari sebuah transaksi, yang kemudian ia investasikan dalam perdagangan, maka begitu jumlahnya meningkat pada jumlah yang harus dibayarkan zakat dan satu tahun telah berlalu dari transaksi pertama, menurut Imam Malik ia harus membayar zakat meskipun jumlah yang harus dizakatkan itu tercapai satu hari sebelum ataupun sesudah satu tahun. Karena itu, tidak ada zakat yang harus dibayarkan sejak hari zakat diambil (oleh pemerintah) sampai dengan waktu satu tahun telah melewatinya.

Imam Abu Hanifah berpendapat bahwa harta penghasilan itu dikeluarkan zakatnya bila mencapai masa satu tahun penuh pada pemiliknya kecuali jika pemiliknya mempunyai harta sejenis yang harus dikeluarkan zakatnya, yang untuk itu zakat harta penghasilan.

Dari beberapa dalil dan pendapatpendapat tersebut di atas, bisa diambil kesimpulan bahwa wajibnya zakat profesi didasarkan pada surat al-Baqarah: 267 yang bersifat umum dan hadits-hadits yang bersifat umum pula, baik keumumannya menyangkut materi hasil usaha, apakah yang diperoleh dari perdagangan, investasi modal, honorarium, gaji, dan sebagainya. Atau keumumannya dari segi waktu yang tidak membatasi harus sudah satu tahun pemilikan harta Untuk menetapkan teknis penerapan ketentuan zakat profesi mulai dari nishab, kadar, dan waktunya menggunakan dalil qiyas (analogical reasoning). Sudah barang tentu menggunakan dalil qiyas sebagai dalil syar'i, harus memenuhi syarat dan rukunnya agar menemukan hukum ijtihadi yang aktual dan proporsional.

\section{Nisab Zakat Profesi dan Cara Perhitungannya}

Nisab merupakan batas minimal atau jumlah minimal harta yang dikenai kewajiban zakat. Karena zakat profesi ini tergolong baru, nisabnya pun mesti dikembalikan (dikiaskan) kepada nishab zakat-zakat yang lain, yang sudah ada ketentuan hukumnya.

Ada dua kemungkinan yang dapat dikemukakan untuk ukuran nishab zakat profesi ini.

1. Disamakan dengan nishab zakat emas dan perak, yaitu dengan mengkiaskannya kepada emas dan perak sebagai standar nilai uang yang wajib dikeluarkan zakatnya, yakni 20 dinar atau 93,6 gram emas. Berdasarkan Hadis Riwayat Daud: 
(Tidak ada suatu kewajiban bagimu-dari emas (yang engkau miliki) hingga mencapai jumlah 20 dinar)

2. Disamakan dengan zakat hasil pertanian yaitu 5 wasq (sekitar $750 \mathrm{~kg}$ beras). Zakatnya dikeluarkan pada saat diterimanya penghasilan dari profesi tersebut sejumlah 5 atau $10 \%$, sesuai dengan biaya yang dikeluarkan.

Karena profesi itu sendiri bermacammacam bentuk, jenis dan perolehan uangnya, penulis cenderung untuk tetap memakai kedua macam standar nisab zakat tersebut dalam menentukan nishab zakat profesi, dengan perimbangan sebagai berikut.

Pertama, Untuk jenis-jenis profesi berupa bayaran atas keahlian, seperti dokter spesialis, akuntan, advokat, kontraktor, arsitek, dan profesi-profesi yang sejenis dengan itu, termasuk juga pejabat tinggi negara, guru besar, dan yang sejajar dengannya, nishab zakatnya disamakan dengan zakat hasil pertanian, yakni senilai kurang lebih $750 \mathrm{~kg}$ beras (5 wasaq). Meskipun kelihatannya pekerjaan tersebut bukan usaha yang memakai modal, namun ia sebenarnya tetap memakai modal, yaitu untuk peralatan kerja, transportasi, sarana kominikasi seperti telephon, rekening listrik, dan lain-lain, zakatnya dikiaskan atau disamakan dengan zakat hasil pertanian yang memakai modal, yakni $5 \%$, dan dikeluarkan ketika menerima bayaran tersebut. Ini sama dengan zakat pertanian yang yang menggunakan biaya irigasi (bukan tadah hujan).

Dengan demikian, jika harga beras $1 \mathrm{~kg}$ Rp. 3200, sedangkan nisab (batas minimal wajib zakat) tanaman adalah $750 \mathrm{~kg}$, maka untuk penghasilan yang mencapai Rp. $3.200 \mathrm{x}$ 750 = Rp. 2.400.000., wajib mengeluarkan zakatnya sebanyak 5\% nya yakni Rp. 120.000.-

Pendapat semacam ini sesuai dengan pendapat Muhammad Ghazali, sebagaimana yang dikutip Yusuf Qardawi, bahwa dasar dan ukuran zakat penghasilan tanpa melihat modalnya, dapat disamakan dengan zakat pertanian yaitu 5 atau 10 persen. Kata Ghazali, siapa yang memiliki pendapatan tidak kurang dari pendapatan seorang petani, terkena kewajiban zakat. Maka gologan profesionalis wajib mengeluarkan zakatnya sebesar zakat petani tersebut, tanpa mempertimbangkan keadaan modal dan persyaratan lainnya.

Seperti ini pula yang ditetapkan oleh Kamar Dagang dan Industri kerajaan Arab Saudi, bahwa penghasilan profesi yang bukan bersifat perdagangan, dikiaskan nisab zakatnya kepada zakat hasil tanam-tanaman dan buahbuahan dengan kadar zakat ssebesar $5 \%$.

Tawaran seperti ini lebih kecil dari yang diusulkan oleh M. Amin Rais, dalam bukunya Cakrawala Islam Antara Cita dan Fakta. Menurutnya profesi yang mendatangkan rizki dengan gampang dan cukup melimpah, setidaknya jika dibandingkan dengan penghasilan rata-rata penduduk, sebaiknya zakatnya ditingkatkan menjadi 10 persen (usyur) atau 20 persen (khumus). Lebih jauh Amin mempersoalkan masih layakkah, profesi-profesi moderen seperti dokter spesialis, komisaris perusahaan, bankir, konsultan, analis, broker, pemborong berbagai konstruksi, eksportir, inportir, notaris, artis, dan berbagai penjual jasa serta macam-macam profesi kantoran (white collar) lainnya, hanya mengeluarkan zakat sebesar 2,5 persen, dan lebih kecil dari petani kecil yang zakat penghasilannya berkisar sekitar 5 sampai 10 persen. Padahal kerja tani jelas merupakan 
pekerjaan yang setidak-tidaknya secara fisik. Cukupkah atau sesuaikan dengan spirit keadilan Islam jika zakat terhadap berbagai profesi moderen yang bersifat making-money tetap 2,5 persen? Layakkah presentasi sekecil itu dikenakan terhadap profesi-profesi yang pada zaman Nabi memang belum ada.

Hemat penulis, pendapat Amin Rais di atas sebenarnya cukup logis dan cukup argumentatif, namun membandingkan profesi dengan rikaz (barang temuan) agaknya kurang tepat. Rikaz diperoleh dengan tanpa usaha sama sekali, sementara profesi membutuhkan usaha dan keahlian serta biaya yang kadangkadang cukup tinggi. Karena itu penulis cenderung untuk menyamakanya dengan zakat pertanian yang memakai biaya irigasi, yakni 5 persen.

Kedua, Bagi kalangan profesional yang bekerja untuk pemerintah misalnya, atau badan-badan swasta yang gajinya tidak mencapai nishab pertanian sebagaimana yang dikemukakan di atas, sebutlah guru misalnya, atau dokter yang bekerja di rumah sakit, atau orang-orang yang bekerja untuk suatu perusahaan angkutan. Zakatnya disamakan dengan zakat emas dan perak yakni 93,6 gram (sekitar Rp. 8.424.000 , jika diperkirakan harga pergram emas sekarang 90.000,) maka nilai nishab emas adalah Rp. Rp. 8.424.000, dengan kadar zakat 2,5\%. Jika pada akhir tahun jumlah mencapai satu nisab, dikeluarkan zakatnya 2,5 persen, setelah dikeluarkan biaya pokok dari yang bersangkutan dan keluarganya.

\section{KESIMPULAN}

Zakat profesi itu hukumnya wajib, sama dengan zakat usaha dan penghasilan lainnya seperti pertanian, peternakan dan

Jurnal Ilmiah Ekonomi Islam- Vol. 01, No. 01, Maret 2015 perdagangan. Batas nisab harta kekayaan yang diperoleh dari usaha profesi dapat disamakan nisabnya dengan zakat hasil tanaman yaitu 5 wasaq (sekitar $750 \mathrm{~kg}$ beras), dengan kewajiban zakat $5 \%$ atau $10 \%$, dan dibayarkan ketika mendapatkan perolehan imbalan atau upah dari profesi tersebut. Bagi profesi-profesi seperti dokter di rumah sakit, guru atau dosen yang hanya menerima gaji tetap dari instansi pemerintah tempat bekerjanya, disamakan nisabnya dengan nisab emas dan perak, yakni 93,6 gram, dengan kewajiban zakat 2,5 persen, yang dikeluarkan setiap satu tahun, dan setelah dikeluarkan biaya kebutuhan pokok.

\section{DAFTAR PUSTAKA}

Ali Hasan. Tuntunan Puasa dan Zakat. Jakarta: PT.Raja Grafindo Persada, 2001). Hlm.204

Amir Syarifuddin. Pembaharuan Pemikiran Dalam Hukum Islam. Jakarta: Logos, 1987

Hadi, Muhammad. Problematika Zakat Profesi \& Solusinya: Sebuah Tinjauan Sosioligi Hukum Islam. Yogyakarta: Pustaka Pelajar, 2010.

Hamid Laonso dan Muhammad Jamil. 2005. Hukum Islam Alternatif: Solusi Terhadap Masalah Fiqh Kontemporer. Jakarta: Restu Ilahi

Inoed, Amiruddin, dkk. 2005. Anatomi fiqh Zakat. Yogyakarta: Pustaka Pelajar

M.Amin Rais. 1999. Cakrawala Islam Antara Cita dan Fakta, Bandung: Mizan 
Muhammad. 2002. Zakat Profesi: Wacana Pemikiran dalam Fiqih Kontemporer. Jakarta: Salemba Diniyah

Sayyid Quthub, Tafsir Fi Zhilaalil Qur'an di Bawah Naungan Al-Qur'an, Terj. Fi Zhilalil Qur'an, Beirut: Daar el-Surq, Jilid I.

Wahab Al Juhairi. 1995. Zakat Kajian Berbagai Madzhab. PT. Remaja Rosdakarya: Bandung

Wikipedia Ensiklopedia Bebas, Zakat profesi.

Zakiah Daradjat. 1996. Zakat Pembersih Harta Dan Jiwa. Jakarta: CV Puhama

Yusuf Qardawi. 2007. Hukum Zakat. Bogor: Litera Antar Nusa

Yusuf Qardlawi. 19976. Fiqhuz-Zakat, Terj. Didin Hafidhuddin, et.al., Bogor: Pustaka Litera Antar Nusa, 1996

https://sadudinm.wordpress.com/resensifilm/zakat-profesi-dalam-perspektifhukum-islam-fiqh/

http://www.tongkronganislami.net/2015/09/tin jauan-umum-tentang-hukum-zakatprofesi.html 